\title{
Rapid Response to Low-Dose Rituximab Following Development of Severe Hemophagocytic Lymphohistiocytosis Due to Epstein-Barr Virus Infection
}

\author{
Namiki Hidemasa ${ }^{\text {a }}$, Yagasaki Hiroshi ${ }^{a}$, b Hirai Maiko ${ }^{\text {a }}$ \\ Morioka Ichiro $^{\mathrm{a}}$
}

\begin{abstract}
Viral infection-associated hemophagocytic lymphohistiocytosis is often observed in children. When Epstein-Barr virus is the pathogen, patients can develop serious coagulopathy and pancytopenia. Usually such patients respond to standard steroid therapy, but alternative therapy for steroid-refractory cases is limited. Here we present the clinical observation of a Japanese girl who was successfully treated with rituximab after she failed to respond to standard steroid therapy.
\end{abstract}

Keywords: Epstein-Barr virus; Hemophagocytic lymphohistiocytosis; Rituximab

\section{Introduction}

Primary hemophagocytic lymphohistiocytosis (HLH) is caused by genetic mutations, while secondary HLH can be caused by infection, malignancy or drugs. Epstein-Barr virus (EBV) is the leading pathogen in secondary HLH. EBV usually infects B-cells but not T-cells, resulting in infectious mononucleosis (IM). Activated T-cells release type-1 cytokines to remove EBV-infected B-cells, following which patients may develop fatal HLH. Although most patients respond to steroid therapy, the use of further steroids, cyclosporine and etoposide have been recommended in refractory patients to suppress the serious cytokine release syndrome [1]. However, etoposide is potentially leukemogenic $[2,3]$. Rituximab, an anti-CD20 antibody, removes CD20+ B-cells efficiently and has been used

Manuscript submitted January 27, 2019, accepted March 4, 2019

aPediatrics and Child Health, Nihon University School of Medicine, Tokyo, Japan

${ }^{\mathrm{b}}$ Corresponding Author: Yagasaki Hiroshi, Pediatrics and Child Health, Nihon University School of Medicine, 30-1 Ohyaguchi-kamicho, Itabashi-ku, Tokyo 173-8610, Japan. Email: yagasaki.hiroshi@nihon-u.ac.jp

doi: https://doi.org/10.14740/ijcp325 for CD20+ lymphoma and EBV-associated post-transplant lymphoproliferative disorder $[4,5]$. Here we report a HLH case successfully treated with rituximab instead of etoposide.

Our case study will add to the current literature providing evidence of an alternative therapy for steroid-refractory HLH, since the efficacy of rituximab has not yet been fully determined.

\section{Case Report}

A 15-year-old girl, who was previously well without remarkable past history was referred to our hospital with 5-day long fever. She did not respond to antimicrobial agents before admission. Her parents are Japanese and have enjoyed a middleclass life style; and the family has not been exposed to a harmful environment, nor does it have any inherited diseases. The physical and neurological examinations that were performed on admission were as follows. The patient's body temperature was $39.8^{\circ} \mathrm{C}$, heart rate was $96 / \mathrm{min}$, respiratory rate was $16 / \mathrm{min}$ and blood pressure (mm Hg) was 108/58. Pharyngeal erythe$\mathrm{ma}$, tenderness in the lower abdomen and splenomegaly were found. There are no other abnormal findings. Laboratory data upon admission were as follows: white blood cells (WBC), 1.0 $\times 10^{9} / \mathrm{L}$; platelet count, $48 \times 10^{9} / \mathrm{L}$; fibrin and fibrinogen degradation product (FDP), $13.9 \mathrm{mg} / \mathrm{L}$; thrombin and anti-thrombin complex (TAT), $26.8 \mu \mathrm{g} / \mathrm{L}$; ferritin, $1,921 \mu \mathrm{g} / \mathrm{L}$ and soluble interleukin-2 receptor, $9,090 \mathrm{U} / \mathrm{mL}$ (Table 1). Bone marrow was hypoplastic and the monocyte fraction was markedly increased (Fig. 1). These findings indicated severe HLH, and so we started prednisolone ( $2 \mathrm{mg} / \mathrm{kg} /$ day) from day 2 post admission (Fig. 2). We immediately performed a multiplex viral DNA screening test including herpes simplex virus (HSV)-1, HSV-2, varicella-zoster virus, EBV, cytomegalovirus, human herpesvirus (HHV)-6, HHV-7, JC virus, BK virus and parvovirus by polymerase chain reaction. On day 4, she presented systemic edema and respiratory failure (body weight of $47.5 \mathrm{~kg}$ at admission increased to $54.5 \mathrm{~kg}$ ). In addition, leukopenia and coagulopathy progressively worsened; WBC, $0.3 \times 10^{9} / \mathrm{L}$; platelet count, 36 $\times 10^{9} / \mathrm{L}$; FDP, $104.6 \mathrm{mg} / \mathrm{L}$ and TAT, $80.2 \mu \mathrm{g} / \mathrm{L}$. Cyclosporine $(6$ $\mathrm{mg} / \mathrm{kg} / \mathrm{day}$, per oral) was then added from day 4 .

EBV-DNA copy number was extremely high $(340,000$ copies $/ \mathrm{mL}$ ), and IgM against EBV viral capsid antigen was 


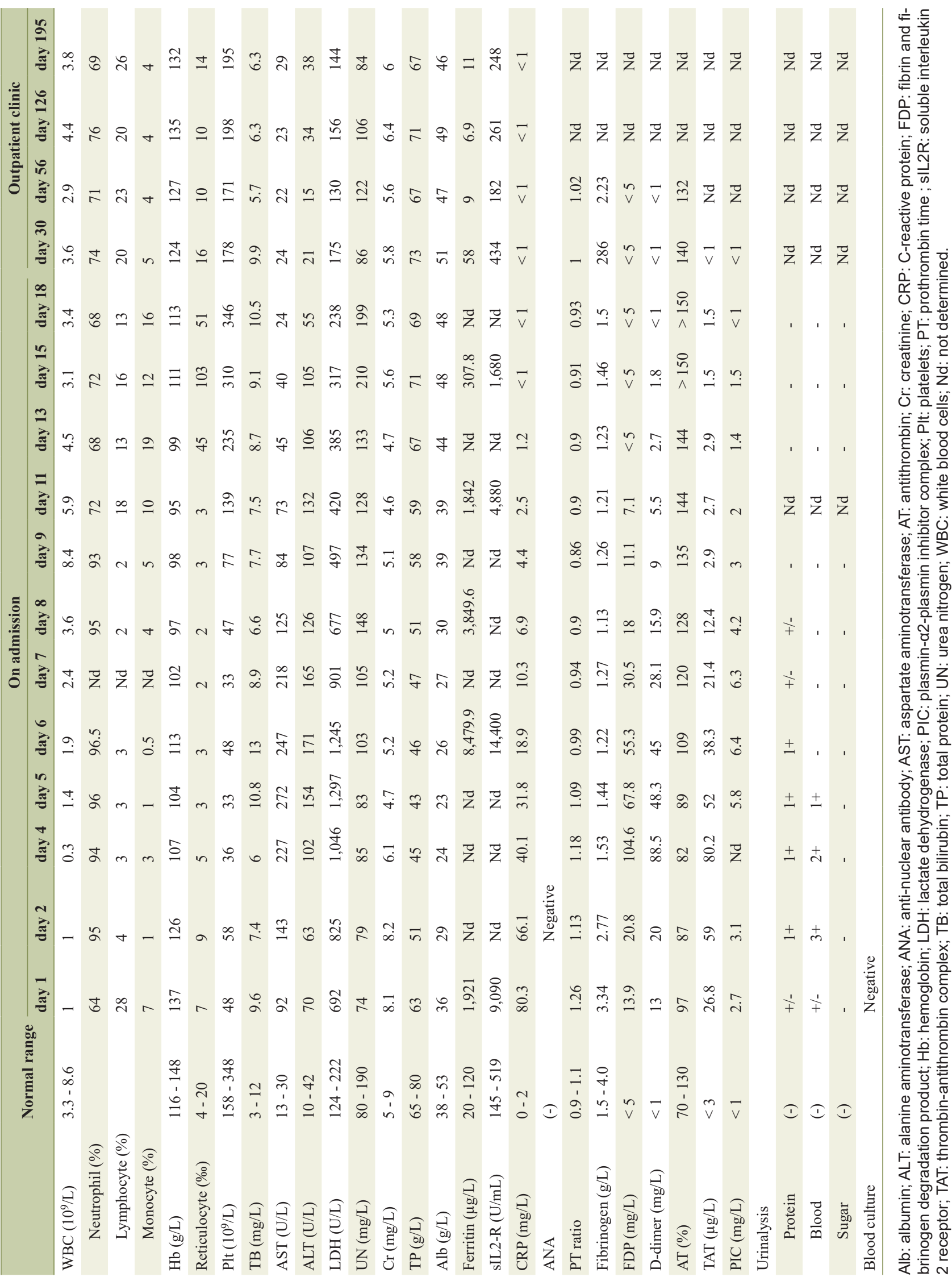




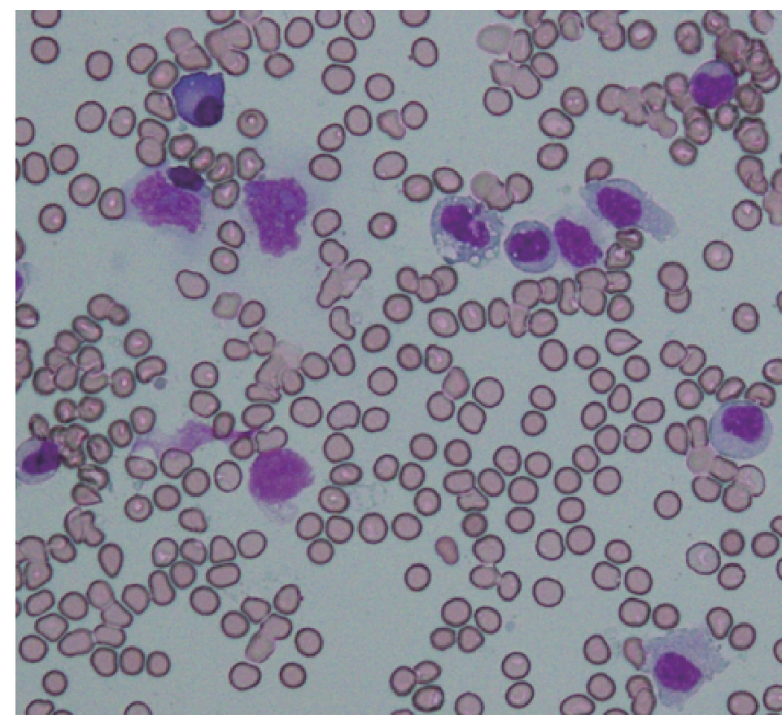

Figure 1. Microscopic findings of bone marrow specimens on day 1. Bone marrow showed monocytic infiltration with a background of hypocellular lesion (May-Giemsa stain, $\times 400$ ). Lymphocytes account for $12 \%$ of total nucleated cells, comprising the following subsets: CD3, 93\%; CD4, 36\%; CD8, 55\%; CD19, 2\%; CD56, 4\%.

increased but anti-EBV nuclear antigen IgG was not detected. Because these findings indicated a primary EBV infection, we decided to use rituximab to remove EBV-infected cells. On day 5 , the first course of rituximab $\left(100 \mathrm{mg} / \mathrm{m}^{2}\right)$ was administered. Surprisingly, her fever and respiratory failure resolved from day 7. WBC and platelet count also began to increase. Coagulopathy and splenomegaly were completely resolved on day 8 . Because EBV-DNA copy number still remained at 4,900 copies $/ \mathrm{mL}$ on day 9 , a second course of rituximab at the same dose was given. On day 16, EBV-DNA was no longer detectable. The patient was discharged at day 20; thereafter prednisolone and cyclosporine were tapered and stopped on day 25 and day 50, respectively. Currently, she is alive and well without any medication.

\section{Discussion}

We report a 15-year-old girl who developed severe pancytopenia and coagulopathy due to primary EBV infection and failed to respond to standard steroid therapy. Etoposide has been widely used in the treatment of such refractory cases, but the concern of secondary malignancy development by the use of cytotoxic drug remains. Here, therefore, we employed rituximab, instead of etoposide, to eradicate EBV-infected CD20+ B-cells. Consequently EBV-DNA disappeared completely after two courses of rituximab.

Indeed, it is difficult to discriminate the following disease entities; IM, EBV-HLH, EBV-associated lymphoma and chronic active EBV infection (CAEBV). Specifying the lineage of EBV-infected cells is useful in determining appropriate treatment because EBV usually infects B-lymphocytes in IM, and $\mathrm{T}$ or NK-cells in CAEBV. However, the pathogenesis of EBV-HLH is controversial. Although Japanese groups concluded that EBV-infected cells were CD8+ T-cells but not Bcells, other investigators have also reported similar case series as the current patient, which suggests B-cells play a central role [6-10]. In this case, we could not identify the infected cell type; however, we strongly suspect that intrasplenic B-cells were involved in this pathogenesis because all the symptoms and findings such as splenomegaly were quickly resolved upon response to rituximab. Finally, the low-dose rituximab (100

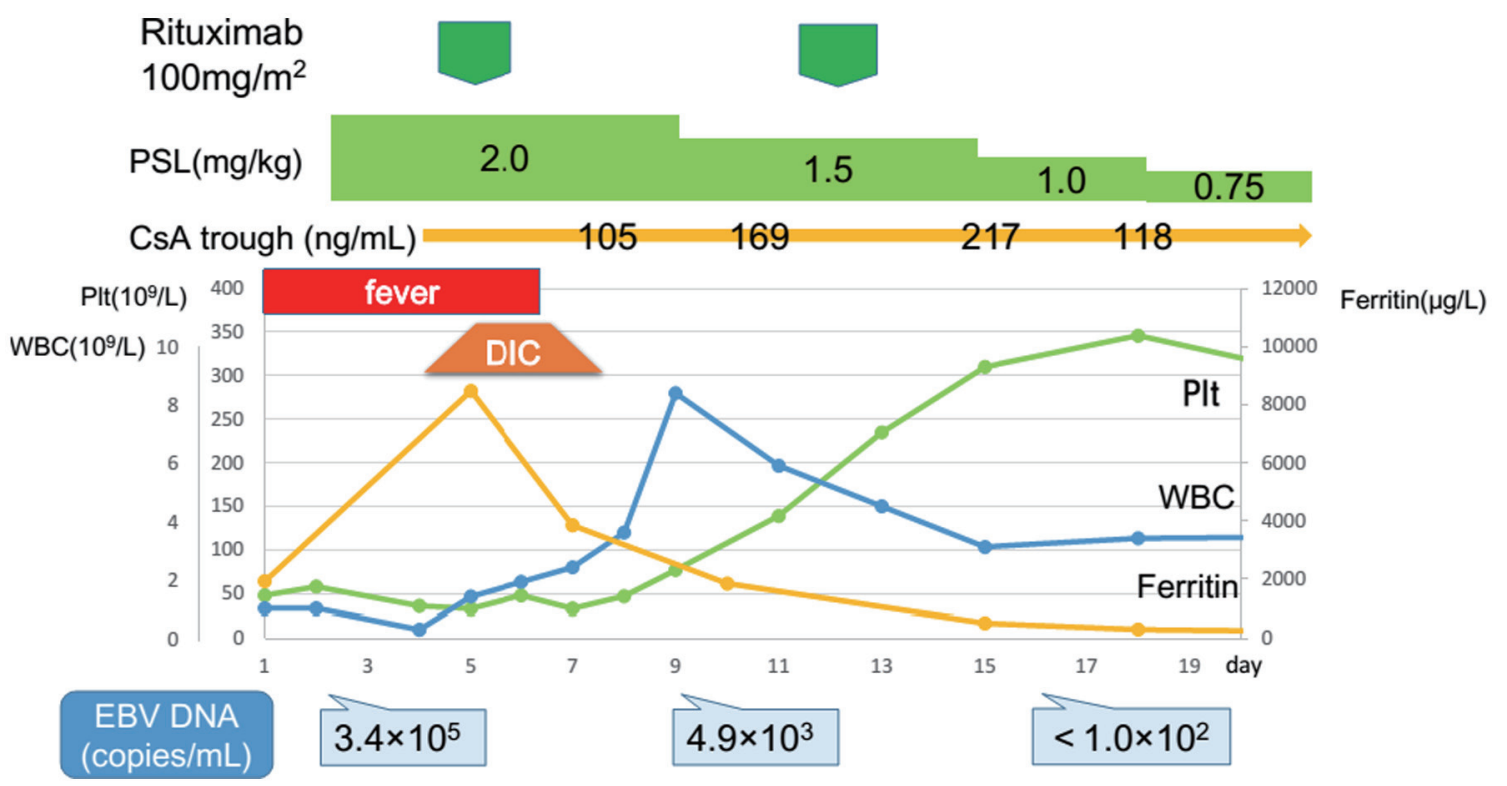

Figure 2. Response to prednisolone, cyclosporine and rituximab. The patient did not respond to first-line therapy with prednisolone. A high level of EBV-DNA was identified on day 4. After the first course of rituximab that was administered on day 5, disease activity rapidly declined. CsA: cyclosporine; DIC: disseminated intravascular coagulation; EBV: Epstein-Barr virus; PIt: platelets; PSL: prednisolone; WBC: white blood cells. 
$\mathrm{mg} / \mathrm{m}^{2}$ ) therapy that we used in this patient has been reported in another study for immune thrombocytopenic purpura [11]. Thus the patient could be treated without any adverse effects such as infusion reaction. In summary, eradicating EBV-infected B-cells with two courses of low-dose rituximab successfully cured EBV-HLH in this patient.

\section{Acknowledgments}

We thank Dr. Shimizu Norio (Department of Virology, Medical Research Institute, Tokyo Medical and Dental University, Tokyo, Japan) for real-time PCR testing of EBV-DNA. We also thank Gillian Campbell, PhD, from Edanz Group (www. edanzediting.com/ac) for editing a draft of this manuscript.

\section{Financial Disclosure}

This study was partially supported by grants from the Ministry of Health, Labor, and Welfare of Japan (Number: H30-KanseiShitei-002).

\section{Conflict of Interest}

All the authors declare no conflict of interests.

\section{Informed Consent}

All procedures performed in this study were in accordance with the ethical standards of the institution, and the $1964 \mathrm{Hel}-$ sinki declaration and its amendments. Based on the approval of the institutional review board, written informed consent was obtained from the guardians of the patient for publication of this case report and for any accompanying images.

\section{Author Contributions}

$\mathrm{HN}$ and HY interpreted the clinical data and performed literature searches. HN prepared the manuscript. HM provided medical care, HY and IM reviewed the manuscript critically and supervised the study. All authors have read and approved the final manuscript.

\section{References}

1. Henter JI, Horne A, Arico M, Egeler RM, Filipovich AH,
Imashuku S, Ladisch S, et al. HLH-2004: Diagnostic and therapeutic guidelines for hemophagocytic lymphohistiocytosis. Pediatr Blood Cancer. 2007;48(2):124-131.

2. Imashuku S, Teramura T, Kuriyama K, Kitazawa J, Ito E, Morimoto A, Hibi S. Risk of etoposide-related acute myeloid leukemia in the treatment of Epstein-Barr virus-associated hemophagocytic lymphohistiocytosis. Int J Hematol. 2002;75(2):174-177.

3. Pan H, Feng DN, Song L, Sun LR. Acute myeloid leukemia following etoposide therapy for EBV-associated hemophagocytic lymphohistiocytosis: a case report and a brief review of the literature. BMC Pediatr. 2016;16:116.

4. Sanz J, Andreu R. Epstein-Barr virus-associated posttransplant lymphoproliferative disorder after allogeneic stem cell transplantation. Curr Opin Oncol. 2014;26(6):677683.

5. Styczynski J, Gil L, Tridello G, Ljungman P, Donnelly JP, van der Velden W, Omar H, et al. Response to rituximab-based therapy and risk factor analysis in Epstein Barr Virus-related lymphoproliferative disorder after hematopoietic stem cell transplant in children and adults: a study from the Infectious Diseases Working Party of the European Group for Blood and Marrow Transplantation. Clin Infect Dis. 2013;57(6):794-802.

6. Kasahara Y, Yachie A. Cell type specific infection of Epstein-Barr virus (EBV) in EBV-associated hemophagocytic lymphohistiocytosis and chronic active EBV infection. Crit Rev Oncol Hematol. 2002;44(3):283-294.

7. Shiraishi A, Ohga S, Doi T, Ishimura M, Takimoto T, Takada H, Miyamoto T, et al. Treatment choice of immunotherapy or further chemotherapy for Epstein-Barr virus-associated hemophagocytic lymphohistiocytosis. Pediatr Blood Cancer. 2012;59(2):265-270.

8. Chellapandian D, Das R, Zelley K, Wiener SJ, Zhao H, Teachey DT, Nichols KE, et al. Treatment of Epstein Barr virus-induced haemophagocytic lymphohistiocytosis with rituximab-containing chemo-immunotherapeutic regimens. Br J Haematol. 2013;162(3):376-382.

9. Balamuth NJ, Nichols KE, Paessler M, Teachey DT. Use of rituximab in conjunction with immunosuppressive chemotherapy as a novel therapy for Epstein Barr virusassociated hemophagocytic lymphohistiocytosis. J Pediatr Hematol Oncol. 2007;29(8):569-573.

10. Al Asad O, Salam A, Mannem S, Ninan M, Markowitz A, Jana B. Alternative therapy for epstein-barr virus related hemophagocytic lymphohistiocytosis. Case Rep Oncol Med. 2015;2015:508387.

11. Li Y, Wang YY, Fei HR, Wang L, Yuan CL. Efficacy of low-dose rituximab in combination with recombinant human thrombopoietin in treating ITP. Eur Rev Med Pharmacol Sci. 2015;19(9):1583-1588. 